\title{
GnRH pulse frequency determines LH pulse amplitude by altering the amount of releasable $\mathrm{LH}$ in the pituitary glands of ewes
}

\author{
I. J. Clarke* and J. T. Cummins*†
}

*Medical Research Centre, Prince Henry's Hospital, St Kilda Road, Melbourne, Victoria 3004 and $\dagger$ Department of Neurosurgery, St Vincent's Hospital, Melbourne, Victoria 3000, Australia

\begin{abstract}
Summary. We have measured the size of the releasable pools of LH and FSH in the pituitary glands of ovariectomized ewes in which the pituitary was isolated surgically from the hypothalamus. The ewes were given $\mathrm{GnRH}$ pulses $(250 \mathrm{ng})$ every hour $(\mathrm{N}=3)$ or every $2 \mathrm{~h}(\mathrm{~N}=3)$ for 1 week and then given a high dose GnRH infusion $(0.5 \mu \mathrm{g} / \mathrm{min})$ for $4 \mathrm{~h}$. Blood samples were collected to characterize the LH and FSH responses to the GnRH pulses and infusion. The LH, but not FSH, responses to the individual GnRH pulses were pulsatile and the amplitudes of the LH pulses were greater in the sheep receiving pulses every $2 \mathrm{~h}$. The sheep receiving hourly pulses showed lower LH responses to the high-dose infusions than did the sheep receiving pulses every $2 \mathrm{~h}$.

These data indicate a relationship between the amplitude of $\mathrm{LH}$ pulses and the size of the releasable pool of LH in the pituitary gland. As the frequency of GnRH pulses is decreased the amplitude of the LH responses is increased in direct proportion to the size of the releasable $\mathrm{LH}$ pool.
\end{abstract}

\section{Introduction}

A major determinant of the amplitude of LH pulses is the frequency with which the pulses occur. In ovariectomized ewes with hypothalamo-pituitary disconnection (Clarke, Cummins, Findlay, Burman \& Doughton, 1984) or in rhesus monkeys with arcuate nucleus lesions (Wildt et al., 1981), the amplitudes of the LH pulses that are generated by replacement with exogenous pulsatile gonadotrophin-releasing hormone (GnRH) are dependent upon the $\mathrm{GnRH}$ pulse frequency. Highfrequency GnRH pulses (1/h) lead to high plasma LH baselines and low plasma LH pulse amplitudes, whereas low-frequency GnRH pulses $(1 / 4 \mathrm{~h})$ lead to low $\mathrm{LH}$ baselines and high LH pulse amplitudes.

In addition to the effects of GnRH pulse frequency, it is possible that LH pulse amplitude is determined by changes in GnRH pulse amplitude (Clarke et al., 1984). At the pituitary level, oestrogen can affect LH pulse amplitude by modifying the responses of the gonadotrophs to GnRH (Reeves, Arimura \& Schally, 1971; Cooper, Fawcett \& McCann, 1974; Yen, Vandenberg \& Siler, 1974; Keye \& Jaffe, 1975).

We have investigated the factors responsible for the changing relationships between GnRH pulse amplitude and LH pulse amplitude in conditions in which the GnRH/LH pulse frequency is changed.

\section{Materials and Methods}

Animals. Mature Merino ewes that had been ovariectomized for at least 1 month were submitted to

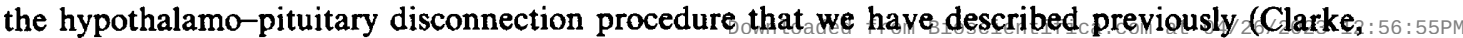


Cummins \& de Kretser, 1983). Since extensive validation of this model, to verify the efficacy of pituitary isolation from the hypothalamus, has been performed on a large number of these sheep in other studies (Clarke et al., 1984; Clarke \& Cummins, 1984), the sheep of the present study were given GnRH replacement injections 2 days after surgery, without oestrogen provocation tests. Before the start of exogenous GnRH treatment, $\mathrm{LH}$ was undetectable $(<0.2 \mathrm{ng} / \mathrm{ml})$ in the peripheral plasma of these sheep. Control ewes were taken from the same flock as the experimental ewes.

During experimentation the sheep were housed in individual pens and given a balanced ration of lucerne and barley and water ad libitum. The cannulation procedures, pulsatile GnRH replacement treatment and blood sampling protocol were as previously described (Clarke et al., 1984).

Hormones. GnRH was purchased from Peninsula Labs, Palo Alto, CA, U.S.A., and stored at $4^{\circ} \mathrm{C}$ in distilled water at a concentration of $100 \mu \mathrm{g} / \mathrm{ml}$ for up to 4 weeks.

Experimental procedure. GnRH replacement for the experimental sheep began 2 days after surgery. Ewes in Group $1(\mathrm{~N}=3)$ received hourly $250 \mathrm{ng} \mathrm{GnRH}$ pulses and those in Group 2 $(\mathrm{N}=3)$ received pulses of $250 \mathrm{ng} \mathrm{GnRH}$ every $2 \mathrm{~h}$. The pulses were administered in $2 \cdot 25 \mathrm{ml}$ saline $(9 \mathrm{~g} \mathrm{NaCl} / \mathrm{l})$ over $6 \mathrm{~min}$ using an automated pulsing device. After 1 week the sheep were given highdose $(0.5 \mu \mathrm{g} / \mathrm{min})$ infusions of $\mathrm{GnRH}$ for $4 \mathrm{~h}$ to obtain estimates of the amount of releasable LH and FSH present in their pituitary glands. The infusions were given via the intra-atrial catheters that had been used previously for GnRH pulsing, beginning at a time when the sheep were due to receive their next $250 \mathrm{ng} \mathrm{GnRH}$ pulse. This treatment was used by Bremner, Findlay, Cumming, Hudson \& de Kretser (1976) to cause maximal LH release in rams. Jugular venous blood samples $(6 \mathrm{ml})$ were collected via indwelling catheters around 2 pulses before the high-dose infusion $(-5$, $+5,+15,+30$ and $45 \mathrm{~min}$ relative to the start of the 6-min GnRH pulse) and $5 \mathrm{~min}$ before and 5, $10,15,20,25,30,35,40,45,50,55,60,70,80,90,100,110$ and $120 \mathrm{~min}$ after the start of the highdose infusion. Over the next $4 \mathrm{~h}$ samples were taken at 15 -min intervals, i.e. until $2 \mathrm{~h}$ after the end of the high-dose infusion.

Four control ovariectomized ewes (Group 3) also received the 4-h high-dose GnRH infusion. Blood samples from these sheep were collected at 15 -min intervals for $2 \mathrm{~h}$ before the start of the high-dose infusion and then at the same times as indicated above for the experimental sheep, after the start of the high-dose infusion. At $2 \mathrm{~h}$ after the end of the high-dose infusion these control ewes were killed and their pituitaries were placed in liquid nitrogen within $5 \mathrm{~min}$ of death for LH and FSH assays. Four other control (untreated) ovariectomized ewes (Group 4) were killed and their pituitaries were collected for LH and FSH assay.

Assays. Plasma LH and FSH were measured by radioimmunoassay (Lee et al., 1976; Bremner, Findlay, Lee, de Kretser \& Cumming, 1980) using NIH-oLH-S18 and NIH-oFSH-S13 as standards. For estimation of pituitary content, the glands were homogenized in $10 \mathrm{ml} 0.1 \mathrm{M}$ $\left(\mathrm{NH}_{4}\right)_{2} \mathrm{SO}_{4}$, put into a shaker bath in iced water for $2 \mathrm{~h}$ and then centrifuged at $1700 \mathrm{~g}$ and $4^{\circ} \mathrm{C}$ for $30 \mathrm{~min}$. The supernatants were then stored at $-15^{\circ} \mathrm{C}$ until assay. The pituitary extracts were serially diluted and showed displacement of labelled hormone in parallel to the assay standards. Assay sensitivity was $0.2-0.4 \mathrm{ng} / \mathrm{ml}$ for LH ( 7 assays) and $1.4-2.7 \mathrm{ng} / \mathrm{ml}$ for FSH (5 assays). Betweenassay coefficients of variation (CV) for $\mathrm{LH}$ assays were $14 \%$ at $32 \mathrm{ng} / \mathrm{ml}, 14 \%$ at $26 \mathrm{ng} / \mathrm{ml}$, and $12 \%$ at $3 \mathrm{ng} / \mathrm{ml}$. For the FSH assays, the between-assay CV was $11 \%$ at $15 \mathrm{ng} / \mathrm{ml}, 18 \%$ at $77 \mathrm{ng} / \mathrm{ml}$ and $16 \%$ at $25 \mathrm{ng} / \mathrm{ml}$. Values were read on that portion of the standard curve where precision was maximal.

Analysis of results. The LH pulse amplitudes, $\mathrm{LH}$ peak heights, $\mathrm{LH}$ baselines and the responses to high-dose infusions in Groups 1, 2 and 3 were compared by analysis of variance and Duncan's multiple range $\mathrm{F}$ test on transformed data. The amounts of $\mathrm{LH}$ released in response to $250 \mathrm{ng}$ $\mathrm{GnRH}$ pulses and in response to the high-dose infusions were estimated by planimetry. 


\section{Results}

In Group 3 (control) ewes the LH response to the high-dose infusion was biphasic (Text-fig. 1). Firstly there was a linear increase in plasma LH concentration which lasted 20-40 min; after a short period during which plasma LH values remained constant or fell slightly, there was a second rise to a peak at $110 \mathrm{~min}$ (1 ewe) or $120 \mathrm{~min}$ ( 3 ewes) after the start of the infusion; thereafter plasma LH levels fell. Plasma FSH values in Group 3 ewes also showed a biphasic response pattern during the constant high-dose GnRH infusion (Text-fig. 1). The first and second peaks were reached 20-35 min and 110-130 min after the start of infusion.
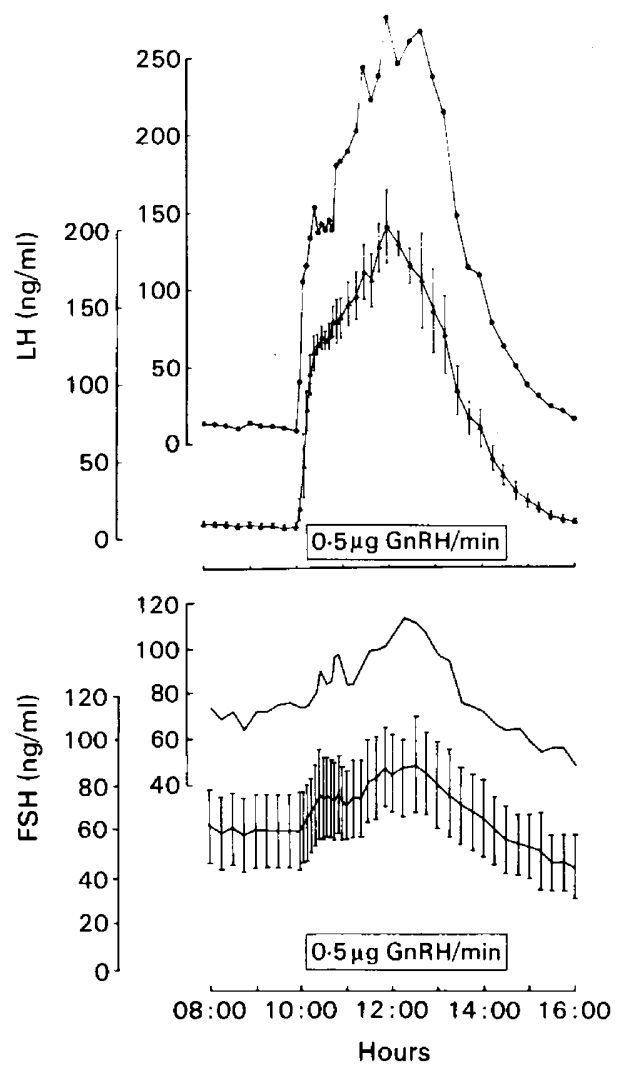

Text-fig. 1. Plasma LH and FSH responses to high-dose infusions of GnRH in ovariectomized ewes in Group 3. The duration of the infusion was $4 \mathrm{~h}(10: 00-14: 00 \mathrm{~h})$. For both hormones, the upper vertical axis and set of data points show the response of an individual animal and the lower vertical axis and lower set of data show mean ( \pm s.e.m.) values for 4 animals (including the values for the single animal).

The mean ( \pm s.e.m.) LH and FSH contents of the pituitaries of Group 3 controls (1969.7 \pm 323.0 and $203.5 \pm 50.9 \mu \mathrm{g} / \mathrm{g}$ wet $\mathrm{wt}$, respectively), which were collected $2 \mathrm{~h}$ after the end of the highdose infusion, were not significantly different from those of Group 4 (untreated) controls (1464.7 \pm 119.5 and $159.9 \pm 25.8 \mu \mathrm{g} / \mathrm{g}$ wet $\mathrm{wt}$ ).

The amplitudes of the LH pulses in Group 1 ewes were significantly $(P<0.05)$ lower than those in Group 2 ewes (Text-figs 2 \& 3). 


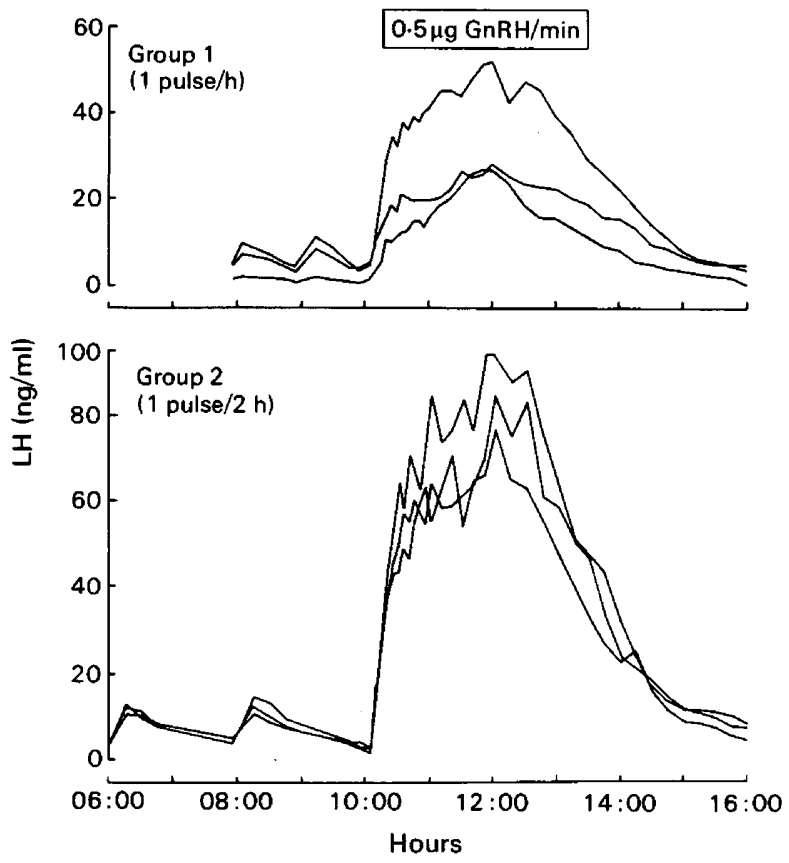

Text-fig. 2. Plasma LH responses to pulsatile and high-dose continuous infusions of GnRH in the experimental ewes in Groups 1 and 2.

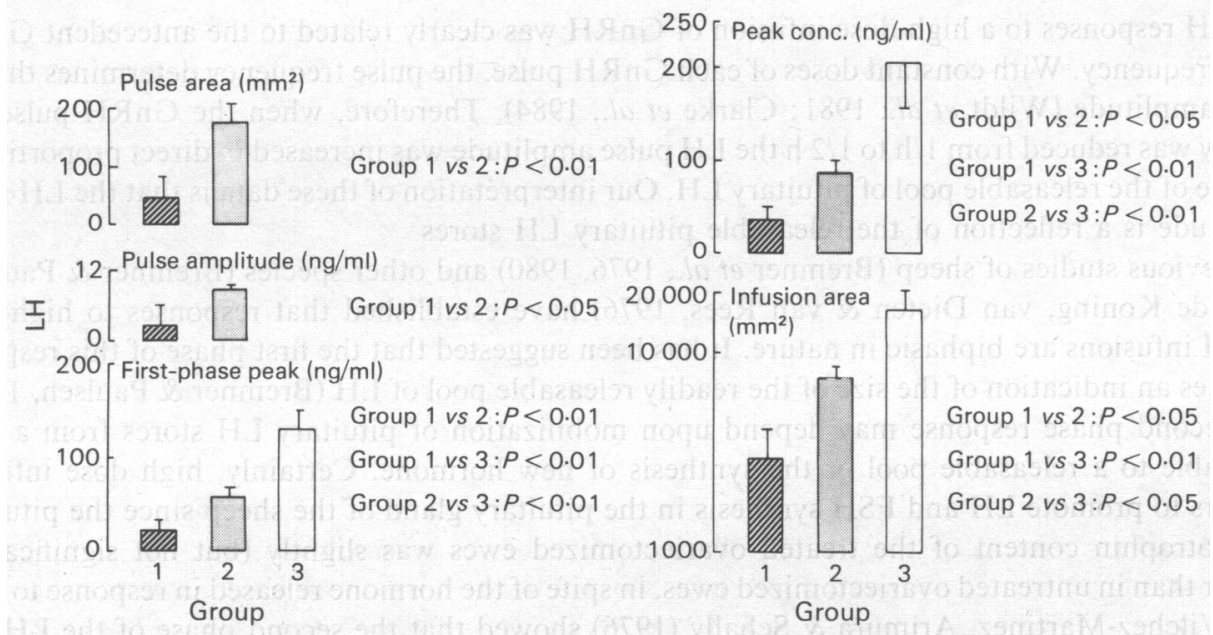

Text-fig. 3. Comparison of plasma LH pulses and responses to high-dose infusions of GnRH in ewes in Groups 1,2 and 3. Pulse area and infusion area were measured by planimetry from graphed data. The 'first-phase peak' values and 'peak concentration' values refer to the firstand second-phase responses during the high-dose GnRH infusions (see Text-fig. 1). Note the $\log$ scale for infusion area.

When the experimental ewes were given high-dose infusions of GnRH at a time when they would otherwise have received $250 \mathrm{ng}$ GnRH pulses, the LH responses were of a form similar to those seen in treated control ewes (Group 3) (Text-fig. 2). The responses in Group 1 ewes were significantly lower than those in Group 2 ewes and those of Groups 1 and 2 were significantly lower 
Table 1. Correlation coefficients indicating the relationships between plasma $\mathrm{LH}$ pulses and responses to high dose $\mathrm{GnRH}$ infusions in ewes in Groups 1 and 2

\begin{tabular}{lcccc}
\hline & $\begin{array}{c}\text { Pulse } \\
\text { amplitude }\end{array}$ & $\begin{array}{c}\text { Pulse } \\
\text { area }\end{array}$ & $\begin{array}{c}\text { Infusion } \\
\text { area }\end{array}$ & $\begin{array}{c}\text { 1st } \\
\text { Peak }\end{array}$ \\
\hline Pulse area & 0.974 & & & \\
Infusion area & 0.940 & 0.974 & & \\
1st Peak & 0.943 & 0.960 & 0.993 & \\
2nd Peak & 0.928 & 0.968 & 0.999 & 0.992 \\
\hline
\end{tabular}

than those in Group 3 (see Text-fig. 3 for levels of significance). In contrast to plasma LH responses, the FSH responses to individual GnRH pulses in the experimental ewes were not pulsatile, although responses to high-dose infusions were apparent (data not shown). Since no FSH pulses were apparent, it was not possible to analyse statistically the relationship between pulsatile FSH output and response to GnRH infusion.

Table 1 shows the relationships between LH pulse amplitude induced by GnRH pulses and the $\mathrm{LH}$ responses to high-dose infusions of GnRH in the experimental ewes. The pulse responses to GnRH expressed as LH pulse amplitude or area under the LH curve were highly correlated with first-phase and second-phase LH responses to the high-dose GnRH infusions. First-phase responses, second-phase responses and total responses were all highly correlated with each other.

\section{Discussion}

The $\mathrm{LH}$ responses to a high-dose infusion of $\mathrm{GnRH}$ was clearly related to the antecedent $\mathrm{GnRH}$ pulse frequency. With constant doses of each GnRH pulse, the pulse frequency determines the LH pulse amplitude (Wildt et al., 1981; Clarke et al., 1984). Therefore, when the GnRH pulse frequency was reduced from $1 / \mathrm{h}$ to $1 / 2 \mathrm{~h}$ the $\mathrm{LH}$ pulse amplitude was increased in direct proportion to the size of the releasable pool of pituitary LH. Our interpretation of these data is that the LH pulse amplitude is a reflection of the releasable pituitary LH stores.

Previous studies of sheep (Bremner et al., 1976, 1980) and other species (Bremner \& Paulsen, 1974; de Koning, van Dieten \& van Rees, 1976) have established that responses to high-dose GnRH infusions are biphasic in nature. It has been suggested that the first phase of this response provides an indication of the size of the readily releasable pool of LH (Bremner \& Paulsen, 1974). The second phase response may depend upon mobilization of pituitary LH stores from a nonreleasable to a releasable pool or the synthesis of new hormone. Certainly, high dose infusion appears to promote LH and FSH synthesis in the pituitary gland of the sheep since the pituitary gonadotrophin content of the treated ovariectomized ewes was slightly (but not significantly) greater than in untreated ovariectomized ewes, in spite of the hormone released in response to infusion. Vilchez-Martinez, Arimura \& Schally (1976) showed that the second phase of the LH and FSH responses to continuous GnRH infusion was partly blocked by actinomycin D whereas the first phase was not. The self-potentiating, or 'priming' effect of GnRH (Pickering \& Fink, 1976) in rats was also reduced by actinomycin $\mathrm{D}$ and by cycloheximide and puromycin. De Koning $e t$ al. (1976) maintained that the second phase of GnRH responsiveness in rats required the synthesis of a protein factor that was not new gonadotrophin. The present results suggest that, in sheep, the second phase depends, at least in part, upon the synthesis of LH and FSH. At present, we have no indication of the extent to which this newly synthesized gonadotrophin enters the releasable pool. The two-pool concept of pituitary LH stores (Bremner \& Paulsen, 1974) (releasable and non-releasable) is supported by the observation that the high-dose GnRH infusion cannot completely deplete the pituitary gland of gonadotrophins, which are presumably in the non-releasable pool. 
In ovariectomized ewes, the FSH response to a high-dose GnRH infusion was biphasic in nature which contrasts with previous results in castrated rams (Bremner et al., 1976). We have no explanation for this sex difference but pituitary gland FSH content is much greater in ewes than in rams (Robertson, Ellis, Foulds, Findlay \& Bindon, 1984). It is possible that the castrated male secretes FSH at a maximal rate whereas the ovariectomized female, with greater FSH stores, does not. Findlay, Gill \& Doughton (1985) have found that castrated male sheep have significantly higher circulating FSH levels than do ovariectomized females.

One explanation of the fact that reducing GnRH pulse frequency increases LH pulse amplitude is that the pituitary glands of the sheep receiving pulses every $2 \mathrm{~h}$ are desensitized to a lesser extent than the pituitary glands of the sheep receiving hourly pulses. We feel that this is an unlikely explanation for the following reasons. Firstly, hourly pulses are not uncommon in our ovariectomized sheep (Clarke \& Doughton, 1983). Secondly, $250 \mathrm{ng}$ pulses of GnRH give peripheral GnRH concentrations of $21-48 \mathrm{pg} / \mathrm{ml}$ (I. J. Clarke, unpublished data) which is within the range of values measured in the hypophysial portal blood plasma of ovariectomized ewes (Clarke \& Cummins, 1982). Thirdly, if the pituitary glands were desensitized by the GnRH treatment then the secretion of gonadotrophins would cease altogether. Fourthly, the GnRH receptor of other ovariectomized ewes with hypothalamo-pituitary disconnection and treated with GnRH pulses is similar to that of ovariectomized controls (I. J. Clarke \& T. M. Nett; unpublished data).

There is no clear reason why the amounts of releasable pituitary LH in the experimental ewes should be less than that of ovariectomized controls: it may be that hypothalamic secretions other than $\mathrm{GnRH}$, and removed by hypothalamo-pituitary disconnection, are important in maintaining the integrity of the gonadotrophs. Also, overiectomized ewes generate a number of small GnRH pulses that do not result in LH pulses (Clarke \& Cummins, 1982) and this may be a reason for the difference between the experimental and control ewes; the small pulses in ovariectomized ewes may act selectively to stimulate synthesis and not secretion.

In conclusion, we have found, by using an in-vivo model in which the amplitude of the GnRH pulses was kept constant and was not compromised by endogenous GnRH secretion, that the amplitude of $\mathrm{LH}$ pulses is directly related to the amount of releasable LH in the pituitary gland. The size of the releasable LH pool, and thus the amplitude of the LH pulses, depends upon the GnRH pulse frequency.

We thank Ms Kathy Burman, Mr Bruce Doughton, Mr Trevor Gill and Mr Paul Weston for technical assistance; the Animal Research Institute, Werribee, for facilities; Dr J. K. Findlay and Professor H. G. Burger for helpful discussions and comments; Professor L. E. Reichert (Jr), Dr A. Parlow and NIH for RIA reagents; and Ms Julie Coleman and Ms Anne Saunders for manuscript preparation. This work was supported by the National Health and Medical Research Council of Australia.

\section{References}

Bremner, W.J. \& Paulsen, C.A. (1974) Two pools of luteinizing hormone in the human pituitary: evidence from constant administration of luteinizing hormone releasing hormone. J. clin. Endocr. Metab. 39, 811-815.

Bremner, W.J., Findlay, J.K., Cumming, I.A., Hudson, B. \& de Kretser, D.M. (1976) Pituitary-testicular responses in rams to prolonged infusions of luteinizing hormone-releasing hormone (LHRH). Biol. Reprod. 15, 141-146.

Bremner, W.J., Findlay, J.K., Lee, V.W.K., de Kretser, D.M. \& Cumming, I.A. (1980) Feedback effects of the testis on pituitary responsiveness to luteinizing hormone-releasing hormone infusions in the ram. Endocrinology 106, 329-336.

Clarke, I.J. \& Cummins, J.T. (1982) The temporal relationship between gonadotropin releasing hormone (GnRH) and luteinizing hormone (LH) secretion in ovariectomized ewes. Endocrinology 11, 1737 1739.

Clarke, I.J. \& Cummins, J.T. (1984) Direct pituitary effects of estrogen and progesterone on gonadotropin secretion in the ovariectomized ewe. Neuroendocrinology 39, 267-274.

Clarke, I.J. \& Doughton, B.W. (1983) Effects of various anaesthetics on resting plasma concentrations of 
luteinizing hormone, follicle stimulating hormone and prolactin in ovariectomized ewes. J. Endocr. 98, 79-89.

Clarke, I.J., Cummins, J.T. \& de Kretser, D.M. (1983) Pituitary gland function after disconnection from direct hypothalamic influences in the sheep. Neuroendocrinology 36, 376-384.

Clarke, I.J., Cummins, J.T., Findlay, J.K., Burman, K.J. \& Doughton, B.W. (1984) Effects on plasma luteinizing hormone and follicle stimulating hormone of varying the frequency and amplitude of gonadotropin-releasing hormone pulses in ovariectomized ewes with hypothalamo-pituitary disconnection. Neuroendocrinology 39, 214-221.

Cooper, K.J., Fawcett, C.P. \& McCann, S.M. (1974) Inhibitory and facilitatory effects of estradiol-17 $\beta$ on pituitary responsiveness to a luteinizing hormonefollicle stimulating hormone releasing factor ( $\mathrm{LH}$ RF/FSH-RF) preparation in the ovariectomized rat. Proc. Soc. exp. Biol. Med. 145, 1422-1426.

de Koning, J., van Dieten, J.A.M.J. \& van Rees, G.P. (1976) LH-RH-dependent synthesis of protein necessary for $\mathrm{LH}$ release from rat pituitary glands in vitro. Molec. cell Endocr. 5, 151-160.

Findlay, J.K., Gill, T.W. \& Doughton, B. (1985) The influence of season and sex on the inhibitory effect of ovine follicular fluid on plasma gonadotrophins in castrated sheep. J. Reprod. Fert. 73, 329-335.

Keye, W.R., Jr \& Jaffe, R.B. (1975) Strength-duration characteristics of estrogen effect on gonadotropin response to gonadotropin releasing hormone in women. 1. Effects of varying duration of estradiol administration. J. clin. Endocr. Metab. 41, 10011008.

Lee, V.W.K., Cumming, I.A., de Kretser, D.M., Findlay, J.K., Hudson, B. \& Keogh, E.J. (1976) Regulation of gonadotrophin secretion in rams from birth to sexual maturity. J. Reprod. Fert. 46, 1-6.

Pickering, A.J.M.C. \& Fink, G. (1976) Priming effect of luteinizing hormone releasing factor: in-vitro and invivo evidence consistent with its dependence upon protein and RNA synthesis. J. Endocr. 69, 373-379.

Reeves, J.J., Arimura, A. \& Schally, A.V. (1971) Changes in pituitary responsiveness to luteinizing hormonereleasing hormone (LHRH) in anestrous ewes pretreated with estradiol benzoate. Biol. Reprod. 4, 8892.

Robertson, D.M., Ellis, S., Foulds, L.M., Findlay, J.K. \& Bindon, B.M. (1984) Pituitary gonadotrophins in Booroola and control Merino sheep. J. Reprod. Fert. 71, 189-197.

Vilchez-Martinez, J.A., Arimura, A. \& Schally, A.V. (1976) Effect of actinomycin $D$ on the pituitary response to LH-RH. Acta endocr., Copenh. 81, 73-81.

Wildt, L., Hausler, A., Marshall, G., Hutchison, J.S., Plant, T.M., Belchetz, P.E. \& Knobil, E. (1981) Frequency and amplitude of gonadotropin-releasing hormone stimulation and gonadotropin secretion in the rhesus monkey. Endocrinology 109, 376-385.

Yen, S.S.C., Vandenberg, G. \& Siler, T.M. (1974) Modulation of pituitary responsiveness to LRF by estrogen. J. clin. Endocr. Metab. 39, 170-177.

Received 18 June 1984 